\title{
Occurrence of Harmful Blue-green Algae at Algae Alert System and Water Quality Forecast System Sites in Daegu and Gyeongsangbuk-do between 2012 and 2019
}

\author{
Chang Yeon $\mathrm{Woo}^{1 \oplus} \cdot$ Sang Leen $\mathrm{Yun}^{2} \cdot$ Seog-ku Kim ${ }^{2} \cdot$ Wontae Lee ${ }^{1,+\oplus}$ \\ 'Department of Environmental Engineering, Kumoh National Institute of Technology \\ ${ }^{2}$ Korea Institute of Civil Engineering and Building Technology
}

(Received November 6, 2020; Revised December 7, 2020; Accepted December 10, 2020)

Objectives: We analyzed the occurrence of blue-green algae at Algae Alert System and Water Quality Forecast System sites in Daegu and Gyeonsangbuk-do between 2012 and 2019.

Methods: Data from 17 sites in Daegu and Gyeonsangbuk-do were collected and reclassified to 8 Nakdong river (ND) sites and 9 water source (WS) sites. Influencing factors on the occurrence of blue-green algae were investigated.

Results and Discussion: At the ND sites, blue-green algae were observed in the range of 0-495,360 cells $/ \mathrm{mL}$. Between 2012 and 2019, the average number of blue-green algae increased as the sites go downstream from ND-1 (Sangju weir) to ND-8 (Dalseong weir), while the number of blue-green algae was lower at the site in-between weirs than the site adjacent to weir. At the WS sites, blue-green algae were observed in the range of $0-112,000$ cells $/ \mathrm{mL}$. The average numbers of blue-green algae in 2014, 2015 and 2017 were higher than those of other years. The dominant species of blue-green algae was Microcystis at all the sites during the summer when the water temperature was high; when the water temperature was low Aphanizomenon had higher rates of dominance. Water temperature was positively correlated with the number of blue-green algae grown, while the dissolved oxygen concentration was found to have a negative correlation with it. $\mathrm{pH}$ and chlorophyll-a were less correlated.

Conclusions: In Daegu and Gyeongsangbuk-do, the main stream of the Nakdong river showed higher blue-green algae occurrence than the water source sites. In most cases, Microcystis was dominant species. In the main stream of Nakdong river, blue-green algae tended to occur more downstream, and the number of blue-green algae was higher at sites close to weir than sites in-between weirs. The occurrence of blue-green algae was highly related to water temperature.

Keywords: Blue-green Algae, Algae Alert System, Water Quality Forecast System, Nakdong River 


\title{
연구논문
}

\section{대구·경북권 조류경보제 및 수질예보제 지점의 유해남조류 발생(2012 2019년) 분석}

\author{
우창연 ${ }^{1 \oplus} \cdot$ 윤상린 $^{2} \cdot$ 김석구 $^{2} \cdot$ 이원태 $^{1,+\odot}$
}

${ }^{1}$ 금오공과대학교 환경공학과

2한국건설기술연구원

목적 : 본 연구에서는 수질예보제를 시행한 2012년부터 조류경보제에 통합되기 이전인 2019년까지의 기간 중 대구. 경북지역 낙동강 수계 및 상수원 구간의 유해남조류 발생 동향을 살펴보았다.

방법 : 조류경보제와 수질예보제 시행 지점 중 대구·경북에 속하는 지점 17 곳의 자료를 수집하여 낙동강 본류에 속 하는 8 지점과 상수원 9 지점으로 분류하여 유해남조류 발생 및 영향인자를 살펴보았다.

결과 및 토의 : 낙동강 본류 측정지점에서는 0 495,360 cells/mL의 범위로 유해남조류가 관측되었다. 2012 2019년 사이 8 년의 평균 유해남조류 발생량은 상주보에서부터 달성보 지점까지 하류로 갈수록 증가하는 추세를 보였다. 보와 보 사이 지점의 유해남조류 발생은 보와 인접한 지점에 비하여 적은 특징이 있었다. 상수원 측정지점에서는 $0 \sim 112,000$ cells $/ \mathrm{mL}$ 의 범위로 유해남조류가 관측되었다. 시기별로는 2014, 2015, 2017년의 유해남조류 발생량이 다른 연도에 비해 많았다. 우점종은 모든 지점에서 Microcystis로 나타났다. 수온이 높은 여름철에는 Microcystis의 발생이 높았고 수온이 낮은 경우 Aphanizomenon이 우점하는 비율이 높았다. 조류경보제와 수질예보제에서 유해 남조류 발생량과 같이 제공되는 인자로는 $\mathrm{pH}, \mathrm{DO}$, 수온, 클로로필-a가 있는데 이 중 수온은 유해남조류 발생량과 양의 상관관계를, $\mathrm{DO}$ 는 음의 상관관계를 나타냈으며, $\mathrm{pH}$ 와 클로로필-a는 상관성이 낮은 것으로 확인되었다.

결론: 대구·경북지역 내 수계에서 낙동강 본류가 상수원 지역에 비해 높은 유해남조류 발생을 보였고, 대부분 Microcystis종이 우점하였다. 낙동강 본류의 경우 하류쪽으로 갈수록 유해남조류 발생이 심해지는 경향이 있었고 보와 근접한 지점이 보와 보 사이의 지점보다 유해남조류 발생 정도가 심한 것으로 나타났다. 유해남조류 발생은 수온과 높은 상관성을 보였다.

주제어 : 남조류, 조류경보제, 수질예보제, 낙동강

\section{1. 서론}

영남지역을 관통하는 낙동강은 이 지역의 최대 수자원 중 하나로 유로연장은 $525 \mathrm{~km}$ 이고 유역면적은 $23,859 \mathrm{~km}^{2}$ 에 달 한다. ${ }^{1-3)}$ 낙동강은 부산광역시, 대구광역시, 울산광역시, 경상 북도, 경상남도 지역 약 1,000 만 인구의 식수원임에도 불구하 고 유역 내 도시의 하·폐수처리시설 방류수 및 비점오염원이 유입되고 있어 수질관리가 중요하다. 1987년 완공된 낙동강 하구언으로 인하여 물 흐름이 정체되는 현상이 발생하여 수위 및 수질 관리에 어려움이 있었으며, 2008 2013년에 걸쳐 건 설된 8개의 보(상주보, 낙단보, 구미보, 칠곡보, 강정고령보, 달성보, 합천창녕보, 창녕함안보)로 인해 물의 체류시간이 증 가하여 낙동강의 환경에 녹조현상 심화 등 여러 가지 변화가 나타났다. ${ }^{4,5)}$
녹조현상은 일차 생산자인 조류(algae)가 서식하기 좋은 환 경이 갖춰지며 대발생하여 하천과 호소를 뒤덮는 현상을 말한 다. 특히 여름 초가을 높은 온도에서 주로 서식하는 남조류가 진한 녹색을 가지기 때문에 녹조현상으로 불린다. 남조류의 대표종인 Microcystis는 남극을 제외한 모든 대륙에서 발생하 고 약 108 개국에서 Microcystis 발생에 관한 문헌이 조회될 정도로 녹조는 전 세계적으로 발생하는 문제이다. ${ }^{6}$ 녹조의 발생은 심미적 문제, 생태계 파괴, 정수처리 공정에 악영향 등 다양한 피해를 준다. 남조류 중 일부 종은 Geosmin과 2-MIB로 대표되는 냄새유발물질을 내놓고 일부 종은 마이크 로시스틴(microcystin) 등 독성물질도 내놓는다. 정수처리시 설에서 냄새유발물질 및 독성물질을 제거하기 위해서는 오존 공정, 활성탄 공정 등 고도처리공정이 필요하며 환경 비용이 증가한다. 
환경부는 녹조현상을 예방하고 국민에게 올바른 정보를 제 공하고자 1998년부터 조류경보제를 운영하였고 2012년에는 조류경보제의 지점이 아닌 4대강 유역에서의 조류를 감시하 고자 수질예보제를 시행하였다. 조류경보제는 조류 발생상황 을 주기적으로 모니터링하고 필요시 경보를 발령하여 수돗물 을 안정적으로 공급하기 위해 하천과 호소 28 개 지점에서 수 온, $\mathrm{pH}$, 용존산소(DO), 클로로필-a, 남조류 세포수 등의 항목을 주 1 회 이상 측정하여 공개하는 제도이다. 조류 세포수가 관심 (1,000 10,000 cells $/ \mathrm{mL})$, 경계(10,000 1,000,000 cells $/ \mathrm{mL})$, 조류 대발생 $(1,000,000$ cells $/ \mathrm{mL}$ 이상), 해제 $(1,000$ cells $/ \mathrm{mL}$ 미만)의 기준으로 2 회 연속 기준을 초과하였을 시 해당 단계를 발령한다. 수질예보제는 4 대강의 16 개의 보 중 조류경보제 시행 지점인 4 개 보를 제외한 12 개의 보에서 공공수역의 사전 예방적 수질 관리를 위하여 시행했던 제도로 기상, 수질, 유량 을 분석하여 7 일간의 수질변화를 예측한 결과를 주 2 회(월, 목) 예보하였다. ${ }^{7)}$ 그러나 조류경보제와 수질예보제가 남조류 세포수를 기반으로 경보를 발령하며 발령 기준이 비슷하여 헷갈린다는 지적이 이어져왔다. 이에 환경부는 다년간에 걸친 분석 끝에 2020년 5월부터 조류경보제와 수질예보제를 통합 하여 운영 중이다. 조류경보제는 신규 지점인 낙동강 물금·매 리 지점을 추가하였고 기존 수질예보제 지점은 모두 조류경보 제의 조류관찰지점으로 표기하였다. 조류경보제의 경우 직관 적인 발령 기준 $(1 \mathrm{~mL}$ 당 유해남조류 세포수 1 천, 1 만, 10 만, 100 만)으로 통일하여 각 단계의 기준을 1 회 초과시 발령, 2 회 미만으로 유지시 해제하는 것으로 단순화하였고 조류 관찰지 점의 경우 경보를 발령하지 않는다.

이처럼 환경부는 매년 발생하는 녹조현상에 유연하게 대처 하기 위해 조류경보제와 수질예보제를 운영해왔고 2020년에 들어서는 수질예보제를 조류경보제와 통합하여 운영하는 등 조류로부터의 피해를 예방하고 국민에게 관련 정보제공과 안 전한 수자원 확보를 위해 노력해 왔다. 본 연구에서는 이러한 노력에도 불구하고 매년 녹조가 대량 발생하여 문제를 겪고 있는 낙동강 유역 중 대구경북에 속하는 지점의 녹조 발생현 황을 수질예보제 시행 직후인 2012년부터 수질예보제의 조류 경보제 통합 직전인 2019년까지 기간으로 알아보고 조류경보 제와 수질예보제에 관해 상호 비교하고자 한다.

\section{2. 연구방법}

\section{1. 대상지점 선정}

본 연구는 조류경보제와 수질예보제 시행 지점 중 대구·경 북 지역에 포함되는 17 개 지점을 분석 대상으로 하였다. 수질 예보제에 해당하는 낙동강의 보 지점은 상주보(ND-1), 낙단보 (ND-2), 구미보(ND-3), 칠곡보(ND-5), 강정고령보(ND-7), 달 성보(ND-8)의 6개소로, 각 보를 기준으로 상류 $500 \mathrm{~m}$ 가 측정 지점이다. 조류경보제 지점은 상수원으로 활용되는 구간으로 공 산지 중앙부(WS-1), 공산지 취수탑(WS-2), 칠곡보 상류 $22 \mathrm{~km}$
(ND-4), 강정고령보 상류 $7 \mathrm{~km}$ (ND-6), 덕동호 댐(WS-3), 안계 호 취수탑(WS-4), 영천호 취수탑(WS-5), 운문호 댐(WS-6), 운문 호 취수탑(WS-7), 진전지 상류(WS-8), 진전지 하류(WS-9) 등 11 개소이다.

수집된 자료의 결과 표기는 수질예보제와 조류경보제로 구 분하지 않고 낙동강 본류에 포함된 6개의 보 지점과 낙동강의 상수원 2개 지점(강정고령보 상류 $7 \mathrm{~km}$, 칠곡보 상류 $22 \mathrm{~km}$ ) 을 묶어 낙동강 지점(ND-1 ND-8)으로 표현하고 나머지 조류 경보제 9개 지점을 묶어 상수원 지점(WS-1 WS-9)으로 표현 하였다.

\section{2. 자료 수집 및 분석}

자료 분석을 위해 국립환경과학원이 운영 중인 '물환경정보 시스템(water.nier.go.kr)'에서 낙동강 수계 중 대구·경북 지역 에 포함되는 지점(보 6개, 상수원 11 개 지점)에 대해 자료를 수집하여 활용하였다. 수집항목은 지점별 조사일, 남조류 세 포수, 우점종, 클로로필-a, 수온 등이다. 우점종 자료의 경우 조류경보제는 유해남조류 4종(Anabeana, Aphanizomenon, Microcystis, Oscillatoria)별 세포수가 개별적으로 제시되어 있 으나, 수질예보제는 유해남조류의 우점종만 표기되어 있다. 측정주기는 기본적으로 주 1 회 이상이나 조류 발생 정도에 따라 주 2 3회의 측정이 이루어졌다. 수집된 자료의 기간은 2012 2019년 사이이었으나, 조류경보제 지점 중 칠곡보 상류 $22 \mathrm{~km}$ (ND-4), 강정고령보 상류 $7 \mathrm{~km}$ (ND-6) 지점은 2016년 부터, 공산지 중앙부(WS-1), 공산지 취수탑(WS-2) 지점은 2014년부터, 진전지 상류(WS-8), 진전지 하류(WS-9) 지점은 2013년부터 각각 측정이 시작되어 해당 지점들은 시작하는 년도부터의 자료를 수집하였다.

조류 및 수질 항목간 상관분석은 SPSS로 하였으며 피어슨 상관계수(Pearson correlation coefficient)를 구하였다. 피어슨 상관계수는 $\mathrm{X}, \mathrm{Y}$ 두 인자의 상관성을 -1 에서 1 사이의 값으로 나타내주는 계수로서 $\mathrm{r}$ 값이 1 에 근접할수록 양의 상관관계를 보이고 -1 에 근접할수록 음의 상관관계를 보이며 0 에 가까우 면 상관성이 없다고 판단한다. 남조류의 발생에는 다양한 인 자가 복잡적인 작용을 통해 만들어진 환경의 영향이 작용한 다. 다만 이번 연구의 특성상 기존에 조류경보제와 수질예보 제를 통해 공개되는 자료만을 활용한 결과이기에 여러 연구를 통해 밝혀진 유해남조류 발생과 연관성이 있는 인자의 복합적 인 상관성을 유추하기에는 무리가 있다고 판단하여 공개되는 인자인 $\mathrm{pH}$, 수온, $\mathrm{DO}, \mathrm{Chl}-\mathrm{a}$ 와 유해남조류 발생량 간 각각의 연관성만을 확인하기 위해 Pearson 상관계수를 사용하였다.

\section{3. 결과 및 고찰}

\section{1. 유해남조류 발생 현황}

2012년부터 2019년 사이 대구-경북지역 낙동강 지점의 월 


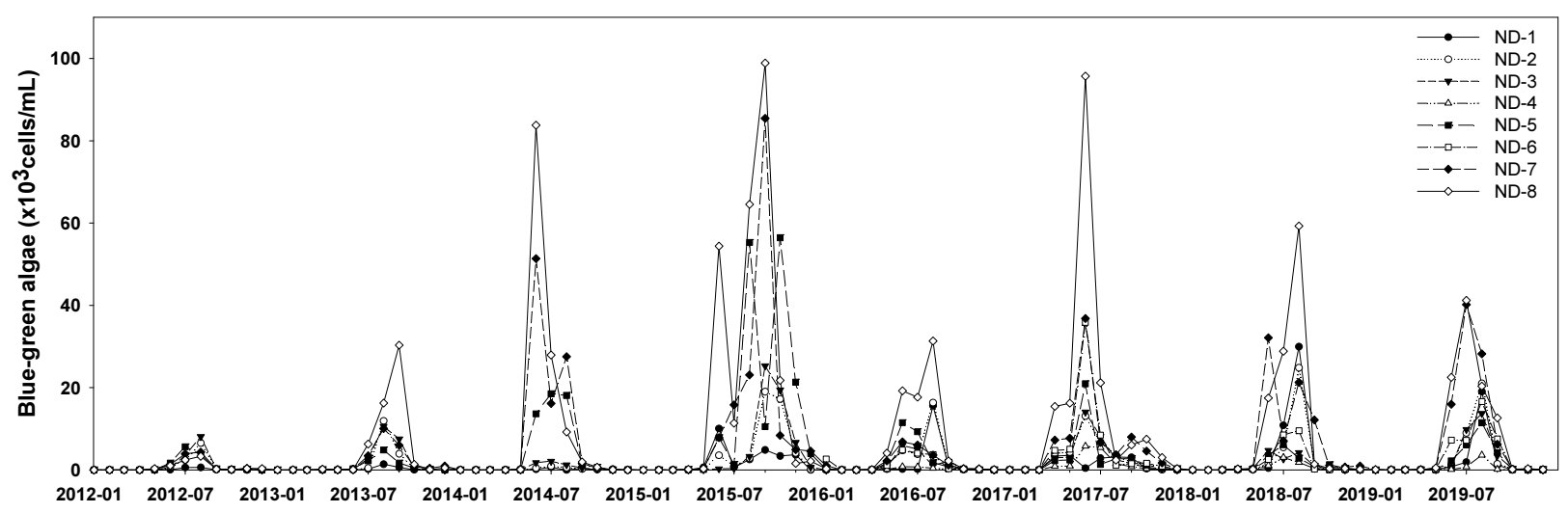

Fig. 1. Variations in monthly averages of blue-green algae cells at Nakdong river sites (ND-1 through ND-8).

평균 유해남조류 발생량을 Fig.1에 정리하였다. 낙동강 지점 의 월별 유해남조류 발생량은 보가 완공되고 난 직후인 2012 년 월평균 10,000 cells $/ \mathrm{mL}$ 을 넘지 않았으나 2013년 최대 30,326 cells $/ \mathrm{mL}, 2014$ 년 최대 83,762 cells $/ \mathrm{mL}, 2015$ 년 최대 $98,888 \mathrm{cells} / \mathrm{mL}$ 로 점차 증가했다가 2016년부터 감소하는 추 세이다. 매년 여름철(6 8월)의 유해남조류 발생량이 높았으 며 낙동강의 하류 지점으로 갈수록 유해남조류 발생 정도가 심해지는 것을 볼 수 있다.

대구·경북 지역 낙동강 지점(ND-1 ND-8) 및 상수원 지점 (WS-1 WS-9)의 2012 2019년 사이 녹조 발생현황을 알 아보기 위해 수집한 데이터를 이용하여 각 지점별로 연도 별 유해남조류 발생량을 분석하였다(Fig. 2, 3). 낙동강 지점 (ND-1 ND-8)은 Fig. 2의 (a) (h)에 보의 위치에 따라 낙동강 상류부터 하류 순서로 나타내었다. 2012년부터 2019년 사이 대구·경북 지역의 낙동강 지점에서 측정된 유해남조류의 최 대치는 495,360 cells $/ \mathrm{mL}$ 이었다. 각 지점별 유해남조류 발생 량의 최대값은 상주보(ND-1) 90,263 cells/mL, 낙단보(ND-2) $89,200 \mathrm{cells} / \mathrm{mL}$, 구미보(ND-3) 79,499 cells $/ \mathrm{mL}$, 칠곡보 상류 $22 \mathrm{~km}$ (ND-4) 24,742 cells $/ \mathrm{mL}$, 칠곡보(ND-5) 300,500 cells $/ \mathrm{mL}$, 강정고령보 상류 $7 \mathrm{~km}$ (ND-6) $51,561 \mathrm{cells} / \mathrm{mL}$, 강정고령보 (ND-7) 261,219 cells $/ \mathrm{mL}$, 달성보(ND-8) 495,360 cells $/ \mathrm{mL}$ 로 낙동강 하류로 갈수록 증가하는 경향을 보였다. 다만, ND-4 와 ND-6지점은 2012 2015년 사이 자료가 없어 자료 분석 및 단순 비교의 한계가 있다.

각 지점별 유해남조류 발생량의 평균은 상주보(ND-1) 1,771 cells $/ \mathrm{mL}$, 낙단보(ND-2) 3,159 cells $/ \mathrm{mL}$, 구미보(ND-3) 2,931 cells $/ \mathrm{mL}$, 칠곡보 상류 $22 \mathrm{~km}$ (ND-4) 632 cells $/ \mathrm{mL}$, 칠곡보 (ND-5) 4,857 cells/mL, 강정고령보 상류 $7 \mathrm{~km}$ (ND-6) 3,565 cells $/ \mathrm{mL}$, 강정고령보(ND-7) 6,875 cells $/ \mathrm{mL}$, 달성보(ND-8) $12,678 \mathrm{cells} / \mathrm{mL}$ 로 하류부인 ND-5 ND-7지점의 발생량 평균 이 상류부인 ND-1 ND-4지점의 발생량 평균보다는 높게 나 타났다. 다만, 앞서 언급한 것과 같이 ND-4와 ND-6지점은 2012 2015년 사이 자료가 없어 자료 분석 및 단순 비교의 한계가 있다.
2016 2019년 사이 자료를 분석하면 칠곡보(ND-5) 지점의 유해남조류 평균 발생량은 칠곡보 상류 $22 \mathrm{~km}$ (ND-4) 지점에 비해 약 2.9 배 높고, 강정고령보(ND-7) 지점의 유해남조류 평 균 발생량은 강정고령보 상류 $7 \mathrm{~km}$ (ND-6) 지점에 비해 약 1.5 배 높아 보에 근접할수록 유해남조류 발생량이 증가했다. 이는 보에 인접한 지점에서 유속 감소에 의한 영향으로 조류 발생이 증가했기 때문으로 판단된다. ${ }^{8)}$

낙동강 지점의 유해남조류 발생은 계절적으로 볼 때 5 10월 에 집중되고 12 2월 겨울철에는 대부분 지점에서 발생하지 않았다. 이는 유해남조류의 발생이 상하류 및 보에서의 거리 에 관계없이 계절적 영향을 크게 받는다는 것을 나타낸다. 수온이 유해남조류 발생에 미치는 영향은 3.3절에서 보다 자 세하게 설명되어 있다.

상수원 지점(WS-1 WS-9)의 유해남조류 발생 현황은 Fig. 3의 (a) (i)에 정리하였다. 상수원 지점의 유해남조류 발생은 낙동강 본류 지점과 비교해서 상당히 적은 수치를 보인다. 이는 상수원 지점(WS-1 WS-9)인 공산지, 덕동호, 안계호, 영 천호, 운문호, 진전지는 모두 상수원 보호구역으로 지정되어 있어 오수, 분뇨, 가축분뇨 등 수질 오염물질의 유입이 적었기 때문으로 판단된다. 2012년부터 2019년 사이 대구·경북 지역 의 상수원 지점에서 측정된 유해남조류의 최대치는 112,000 cells $/ \mathrm{mL}$ 이었다.

각 지점별 유해남조류 발생량의 최대값은 공산지 중앙부 (WS-1) 112,000 cells/mL, 공산지 취수탑(WS-2) 40,250 cells/mL, 덕동호 댐(WS-3) $1,582 \mathrm{cells} / \mathrm{mL}$, 안계호 취수탑(WS-4) 6,733 cells $/ \mathrm{mL}$, 영천호 취수탑(WS-5) 9,748 cells $/ \mathrm{mL}$, 운문호 댐 (WS-6) 3,320 cells $/ \mathrm{mL}$, 운문호 취수탑(WS-7) 3,801 cells/mL, 진전지 상류(WS-8) 213 cells $/ \mathrm{mL}$, 진전지 하류(WS-9) 222 cells $/ \mathrm{mL}$ 로 나타났다. 각 지점별 유해남조류 발생량의 평균은 공산지 중앙부(WS-1) 4,839 cells $/ \mathrm{mL}$, 공산지 취수탑(WS-2) 2,269 cells $/ \mathrm{mL}$, 덕동호 댐(WS-3) 112 cells $/ \mathrm{mL}$, 안계호 취수탑 (WS-4) 382 cells $/ \mathrm{mL}$, 영천호 취수탑(WS-5) 397 cells $/ \mathrm{mL}$, 운문 호 댐(WS-6) $70 \mathrm{cells} / \mathrm{mL}$, 운문호 취수탑(WS-7) $70 \mathrm{cells} / \mathrm{mL}$, 진전지 상류(WS-8) 1 cells $/ \mathrm{mL}$, 진전지 하류(WS-9) 2 cells $/ \mathrm{mL}$ 


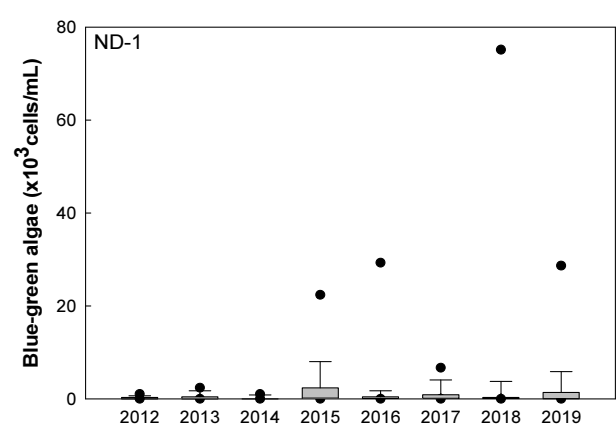

(a) ND-1 $(n=431)$

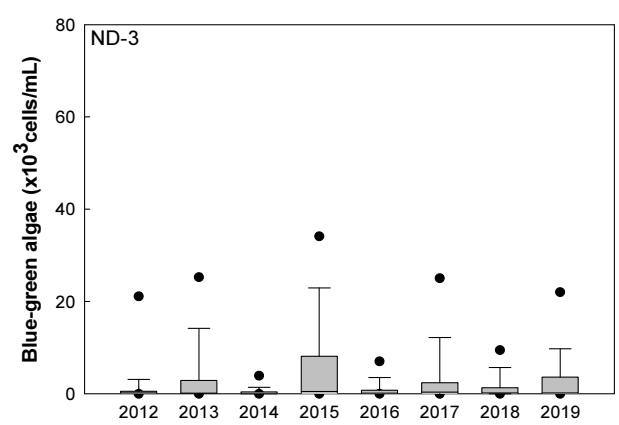

(c) ND-3 $(n=445)$

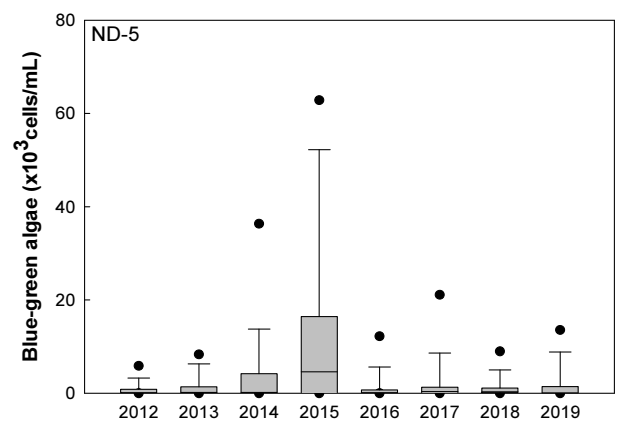

(e) ND-5 $(n=460)$

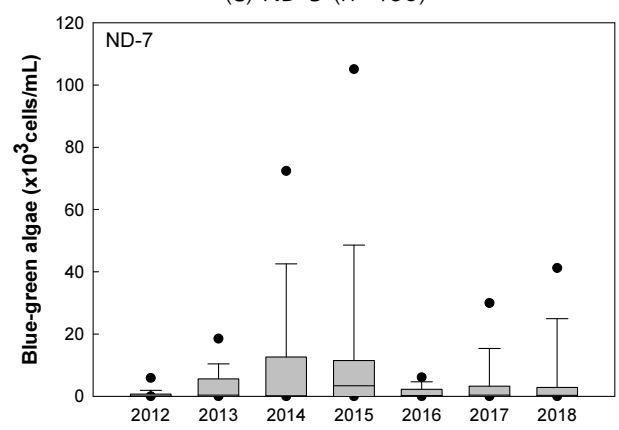

(g) ND-7 $(n=474)$

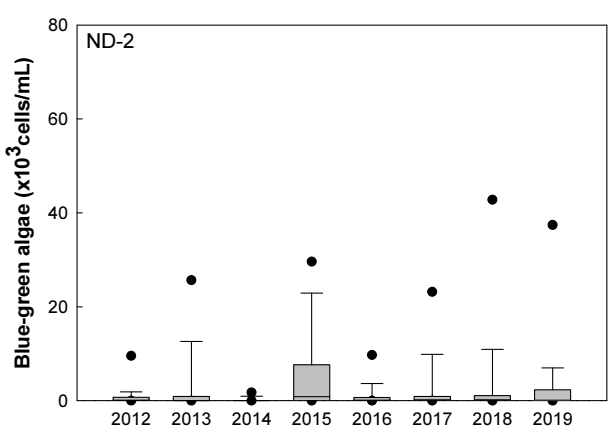

(b) ND-2 ( $n=435)$

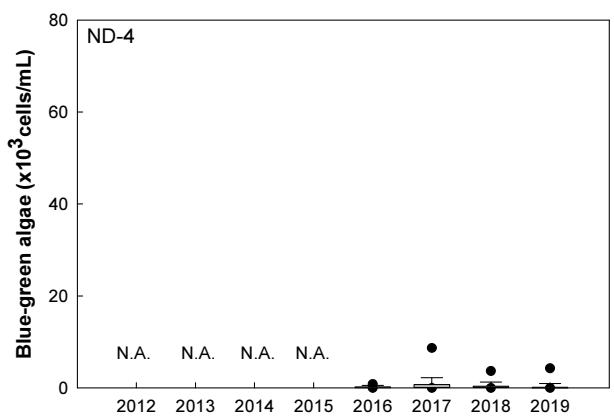

(d) ND-4 $(n=191)$

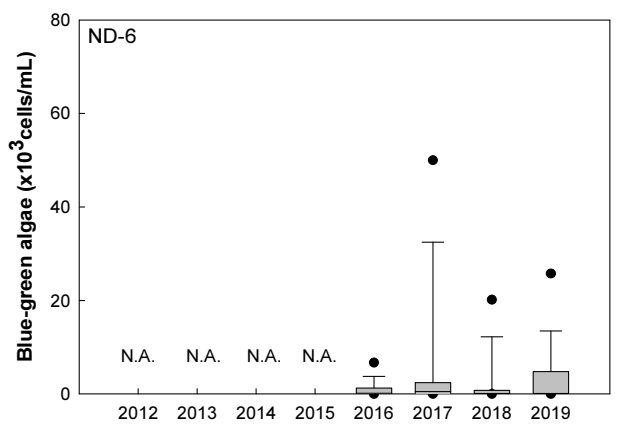

(f) ND-6 ( $n=204)$

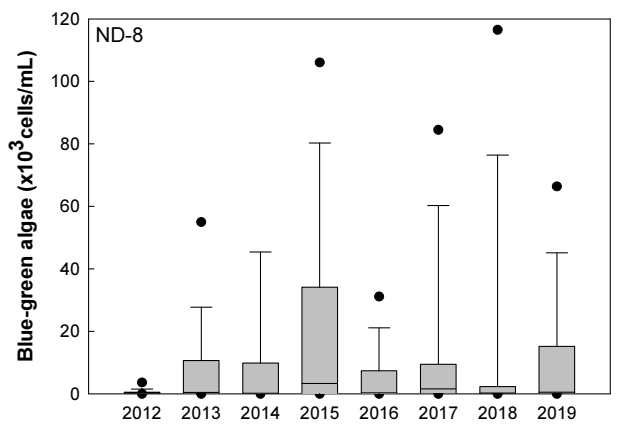

(h) ND-8 $(n=530)$

Fig. 2. Box and whisker plots of numbers of blue-green algae cells by year at study sites, ND-1 through ND-8.

로 나타났다. 상수원 지점의 유해남조류 발생도 낙동강 지점과 유사하게 계절적으로 볼 때 5 10월에 발생되고 12 2월 겨울 철에는 대부분 지점에서 발생하지 않았다.

\section{2. 남조류 종 비율 및 우점종}

유해남조류 4종(Microcystis, Anabaena, Oscillatoria, Aphanizomenon)의 우점 비율을 Fig.4에 나타내었다. 2012 2019
년 사이 낙동강 지점(ND-1 ND-8)에서 가장 우점비율이 높았 던 종은 Microcystis이었고, 조류 종의 우점 비율은 지점에 따라 Microcystis 47 63\%, Anabaena 0 11\%, Oscillatoria 0 5\%, Aphanizomenon 29 47\% 사이로 나타났다(Fig. 4(A)). 낙동 강 지점(ND-1 ND-8)은 남조류 종의 비율이 지점별로 큰 차이 를 나타내지 않았으나, 하류로 갈수록 Microcystis의 비율이 다소 증가하는 추세를 나타냈다. 낙동강 지점은 우점종의 종류 


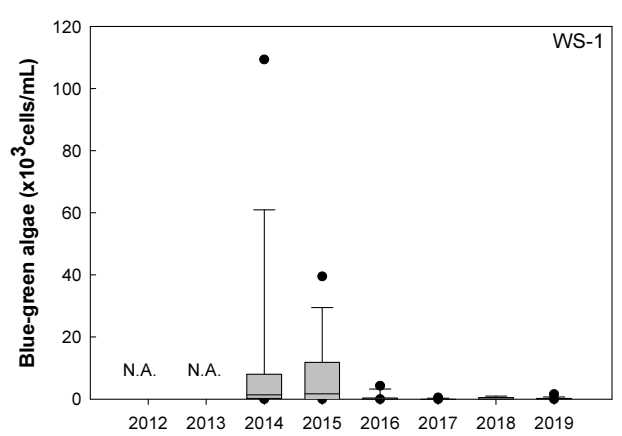

(a) WS-1 $(n=234)$

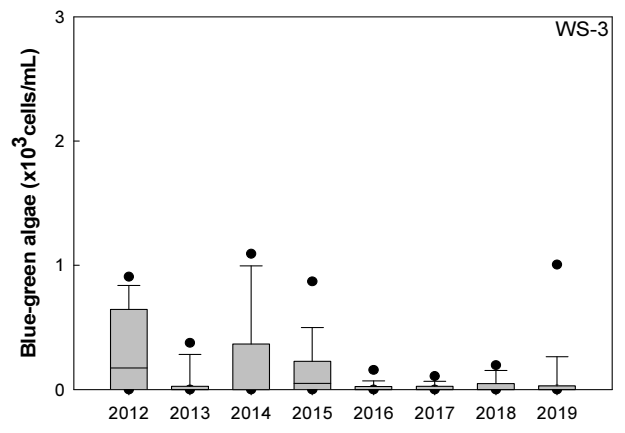

(c) WS-3 $(n=390)$

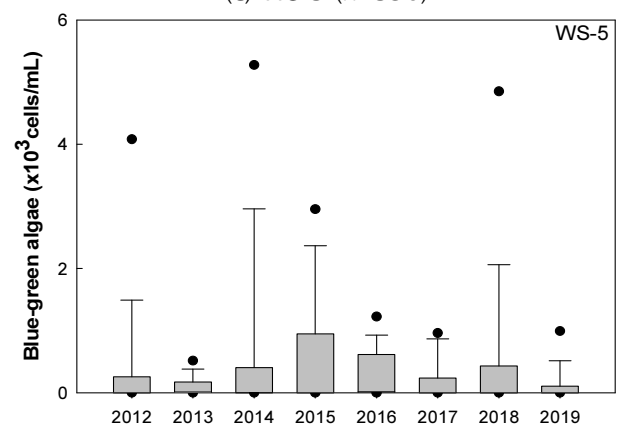

(e) WS-5 $(n=396)$

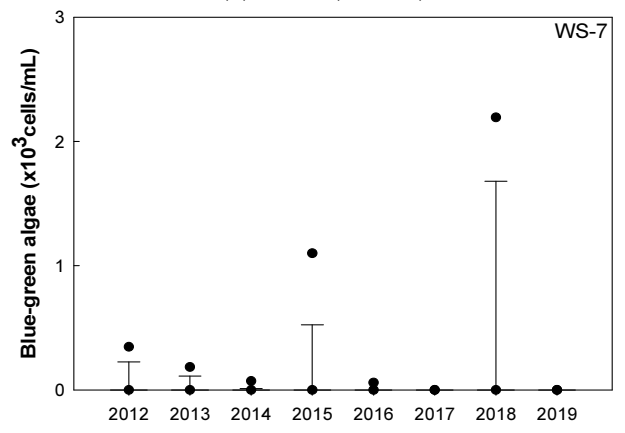

(g) WS-7 $(n=390)$

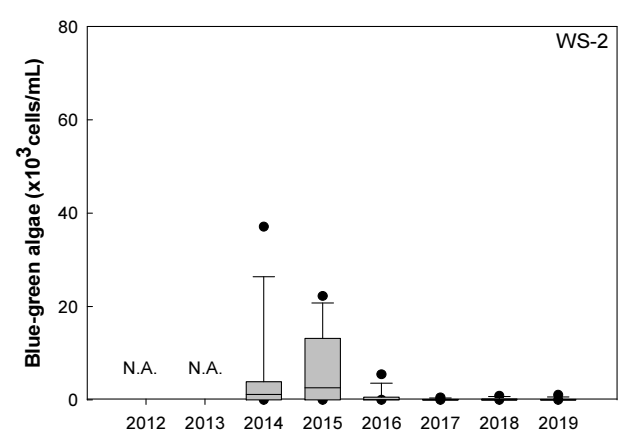

(b) WS-2 $(n=298)$

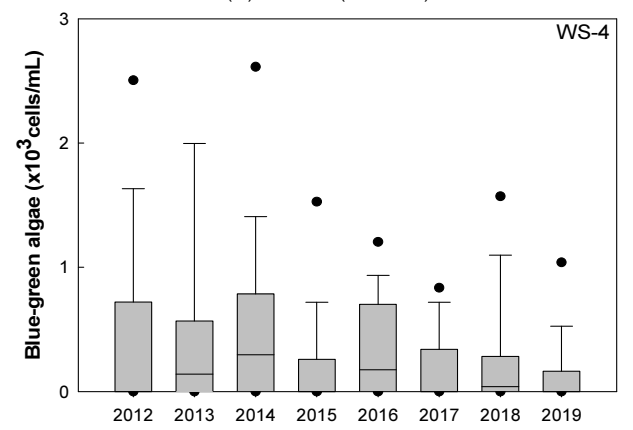

(d) WS-4 $(n=397)$

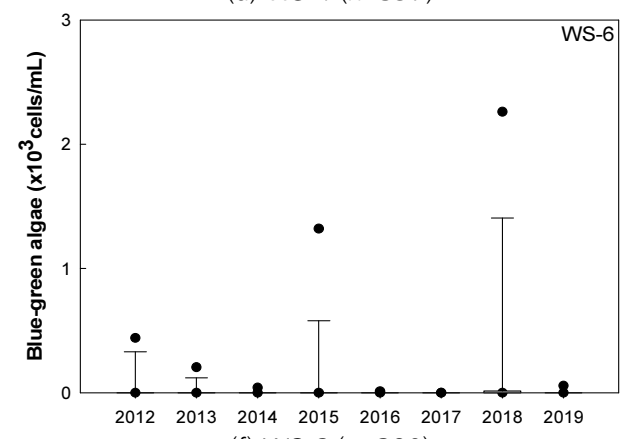

(f) WS-6 $(n=390)$

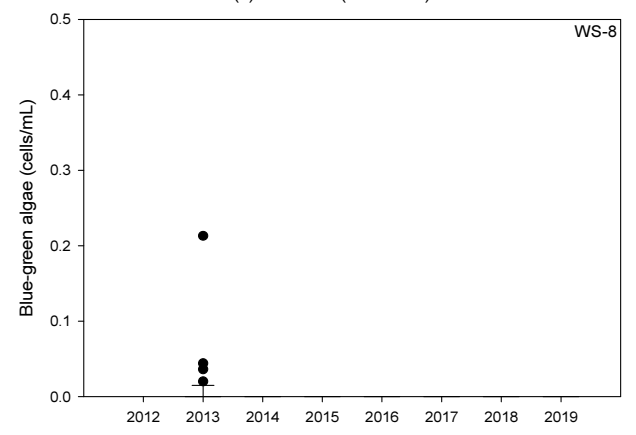

(h) WS-8 $(n=349)$

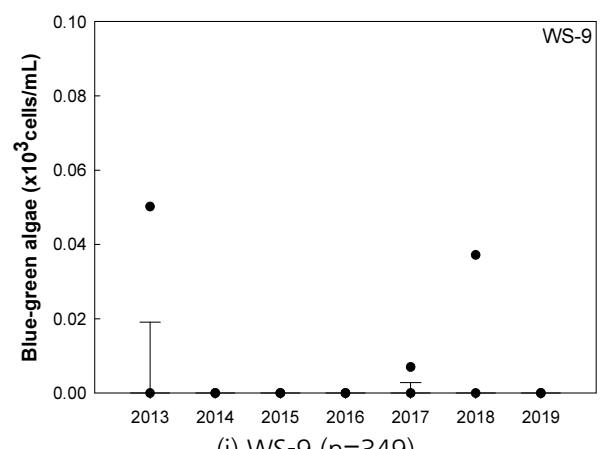

Fig. 3. Box and whisker plots of numbers of blue-green algae cells by year at study sites, WS-1 through WS-9. 


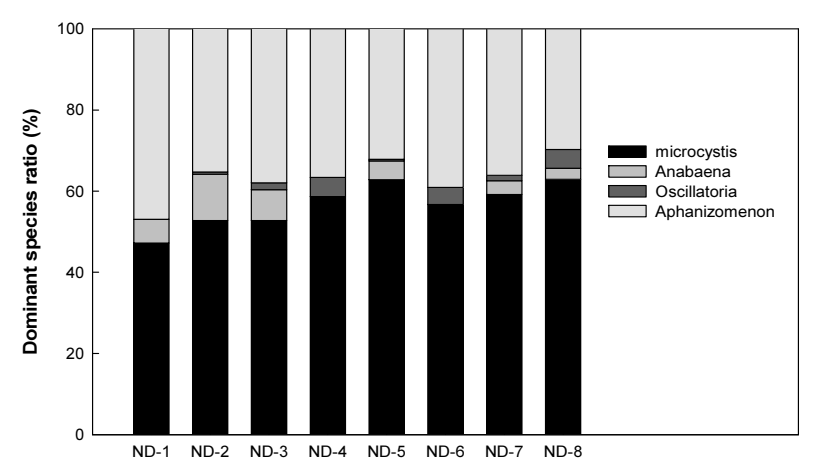

(A)

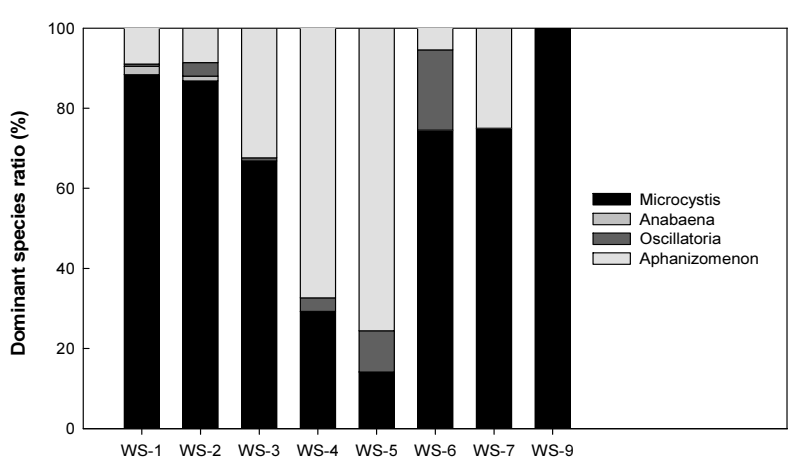

(B)

Fig. 4. Dominant species ratio of algae occurred at study sites (A: ND-1 ND-8, B : WS-1 WS-9).

자료만 있고 종별 세포수 자료는 없어서 이에 대한 분석은 할 수 없었다.

상수원 지점(WS-1 WS-9) 중 진전지 상류(WS-8) 지점은 우점종 자료가 없어 제외하고 나머지 지점을 대상으로 분석하 였다(Fig.4(B)). 2012 2019년 사이 상수원 지점(WS-1 WS-9) 에서 가장 우점비율이 높았던 종은 지점에 따라 다르게 나타났 는데 공산지 중앙부(WS-1), 공산지 취수탑(WS-2), 덕동호 댐 (WS-3), 운문호 댐(WS-6), 운문호 취수탑(WS-7), 진전지 하류 (WS-9)에서는 Microcystis의 비율이 높았으나, 안계호 취수탑 (WS-4)과 영천호 취수탑(WS-5)에서는 Aphanizomenon의 비율 이 높았다. 조류 종의 우점 비율은 지점에 따라 Microcystis 14 100\%, Anabaena 0 2\% Oscillatoria 0 20\%, Aphanizomenon $0 \sim 76 \%$ 사이로 나타났다.

상수원 지점(WS-1 WS-9) 중 안계호와 영천호를 제외하면 Microcystis의 우점 비율은 49\% 이상이었다. 종별 세포수가 표기되는 상수원 지점의 자료를 살펴보면 유해남조류 발생량 은 대부분이 Microcystis로 나타나 발생 개체수로도 Microcystis 가 가장 많았는데, 이는 $28 \sim 32^{\circ} \mathrm{C}$ 에서 최대 성장률을 보이는 Microcystis 가 여름철에 대량 발생하기 때문이다.9) Microcystis 다음으로 많은 우점 비율을 보인 Aphanizomenon은 23 29 $9^{\circ} \mathrm{C}$ 정도의 수온을 선호하는 종이나 타 남조류에 비해 높은 저온 내성을 가지고 있어 늦가을에서 봄철에 주로 우점하였다. ${ }^{10}$
낙동강 지점과 상수원 지점의 우점 횟수를 살펴보면 하천인 낙동강의 경우 대체로 일정한 우점 비율을 보인다는 특징이 있었고 호소인 상수원 지점의 경우 일관성을 보이지 않으며 지점마다 다양한 우점 비율을 나타냈다. 호소의 유해 남조류 발생은 호소별로 개별적인 특성을 보였고 하천과 비교하여 종다양성이 높게 나타났다. 이러한 경향은 금강유역을 대상으 로 한 타 연구와도 유사한 결과이다. ${ }^{1)}$

\section{3. 유해남조류 발생과 수질인자의 상관관계}

낙동강 지점(ND-1 ND-8)과 상수원 지점(WS-1 WS-9)의 유해남조류 세포수와 수질인자(수온, $\mathrm{pH}, \mathrm{DO}$, 클로로필-a) 간 의 상관계수를 분석하여 Table1과 Table2에 정리하였다. 유 해남조류 세포수는 범위가 넓어 log-scale에 대한 상관계수도 함께 분석하였다. 진전지 상류(WS-8) 지점은 2013 2014년 사이 $\mathrm{pH}$ 와 DO 값이 측정되지 않았고 2015 2019년 사이에는 유해남조류 발생이 없었기에 $\mathrm{pH}$ 와 DO 항목에 대한 상관계수 를 구하지 못하였다.

낙동강 지점(ND-1 ND-8) 자료의 경우 유의성이 있는 상관 관계를 보이는 것은 log-scale 남조류 세포수와 수온(all data, $\mathrm{r}=0.71$ ), $\log$-scale 남조류 세포수와 DO (all data, $\mathrm{r}=-0.66$ )로 나타났다(Table 1). 낙동강 지점별 남조류 세포수를 log-scale 로 표현하면 수온과 $0.64 ~ 0.77$ 의 양의 상관관계를 보였고, DO

Table 1. Correlation coefficients between blue-green algae cell density and water quality parameters at Nakdong river sites(ND-1 ND-8).

\begin{tabular}{cccccccccc} 
& \multicolumn{3}{c}{ Blue-green algae cell density } & \multicolumn{4}{c}{ Blue-green algae cell density (log-scale) } \\
\cline { 2 - 11 } ND-1 & Water temperature & pH & DO & Chl-a & Water temperature & pH & DO & Chl-a \\
\hline ND-2 & 0.25 & 0.14 & -0.20 & 0.17 & 0.64 & 0.17 & -0.56 & 0.21 \\
\hline ND-3 & 0.33 & 0.24 & -0.25 & 0.07 & 0.71 & 0.13 & -0.62 & 0.04 \\
\hline ND-4 & 0.33 & 0.13 & -0.22 & 0.03 & 0.74 & 0.02 & -0.64 & 0.06 \\
\hline ND-5 & 0.30 & 0.03 & -0.27 & 0.02 & 0.77 & -0.17 & -0.72 & 0.07 \\
\hline ND-6 & 0.19 & 0.09 & -0.22 & -0.07 & 0.71 & -0.04 & -0.70 & -0.20 \\
\hline ND-7 & 0.37 & 0.28 & -0.28 & 0.14 & 0.75 & 0.23 & -0.66 & 0.15 \\
\hline ND-8 & 0.28 & 0.02 & -0.31 & -0.09 & 0.73 & -0.09 & -0.74 & -0.26 \\
\hline ALL & 0.32 & 0.16 & -0.28 & -0.03 & 0.75 & -0.04 & -0.70 & -0.27 \\
\hline
\end{tabular}


Table 2. Correlation coefficients between blue-green algae cell density and water quality parameters at water source sites (WS-1 WS-9).

\begin{tabular}{cccccccccc} 
& \multicolumn{3}{c}{ Blue-green algae cell density } & \multicolumn{3}{c}{ Blue-green algae cell density (log-scale) } \\
\cline { 2 - 10 } Wite-1 & Water temperature & pH & DO & Chl-a & Water temperature & pH & DO & Chl-a \\
\hline WS-2 & 0.30 & 0.32 & 0.07 & 0.15 & 0.61 & -0.02 & -0.34 & 0.19 \\
\hline WS-3 & 0.34 & 0.07 & -0.12 & 0.12 & 0.64 & -0.20 & -0.48 & 0.11 \\
\hline WS-4 & 0.40 & 0.20 & -0.22 & 0.21 & 0.57 & 0.16 & -0.45 & 0.14 \\
\hline WS-5 & 0.36 & -0.26 & -0.34 & -0.07 & 0.39 & -0.34 & -0.43 & -0.11 \\
\hline WS-6 & 0.30 & -0.06 & -0.31 & 0.15 & 0.46 & -0.10 & -0.52 & -0.03 \\
\hline WS-7 & 0.20 & 0.09 & -0.11 & 0.01 & 0.31 & 0.10 & -0.19 & -0.02 \\
\hline WS-8 & 0.16 & 0.03 & -0.16 & 0.01 & 0.30 & 0.16 & -0.21 & 0.00 \\
\hline WS-9 & 0.09 & - & - & 0.25 & 0.15 & - & - & 0.36 \\
\hline ALL & 0.15 & -0.08 & -0.09 & 0.17 & 0.24 & -0.08 & -0.19 & 0.29 \\
\hline
\end{tabular}

농도와 $-0.74 \sim 0.56$ 의 음의 상관관계를 보였다. 즉 수온이 높 을 때 남조류가 많이 발생했고, 남조류 생성이 증가할 때 DO 농도는 감소했음을 알 수 있다. 상수원 지점(WS-1 WS-9)에서 는 남조류 세포수를 log-scale로 비교해도 수온 $(\mathrm{r}=0.15 \sim 0.64)$ 및 $\mathrm{DO}(\mathrm{r}=-0.52 \sim-0.19)$ 와 낙동강 지점에 비해 낮은 상관관계 를 보였다(Table2). 공산지 지점(WS-1, WS-2)에서만 남조류 세포수와 수온이 상관계수 0.6 이상을 나타냈다.

Fig. 5는 낙동강 지점(ND-1 ND-8)과 상수원 지점(WS-1 WS-9)의 지점별 2015 2019년 유해남조류 발생과 수온의 관 계를 나타낸다. 낙동강 지점의 유해남조류 발생은 수온 $20^{\circ} \mathrm{C}$ 이하에서 대부분 $10,000 \mathrm{cells} / \mathrm{mL}$ (조류경보 경계단계 기준)를 넘지 않았으나 $20^{\circ} \mathrm{C}$ 에서부터 수온이 증가함에 따라 유해남조 류 발생이 급격히 증가하는 경향성을 보인다. 상수원 지점에 서도 비슷한 경향을 보여 유해남조류 발생이 수온 $20^{\circ} \mathrm{C}$ 이하 에서 대부분 1,000 cells $/ \mathrm{mL}$ (조류경보 관심단계 기준)를 넘지 않았다. 정도의 차이는 있으나 모든 지점에서 수온이 $20^{\circ} \mathrm{C}$ 이상으로 증가함에 따라 유해남조류 발생량이 많아지는 경향 이 있으므로 수온이 높은 초여름 가을 사이에는 분석 횟수를 늘려 유해남조류 발생 관리 및 예방에 더욱 신경 써야 할 것으 로 판단된다.

Fig. 6은 낙동강 지점(ND-1 ND-8)과 상수원 지점(WS-1 WS-9) 의 지점별 유해남조류 발생과 $\mathrm{DO}$ 의 관계를 나타낸다. 상수원 구간에 비해 비교적 유해남조류 발생량이 많은 낙동강 지점에 서 유해남조류 발생이 많을수록 DO 농도가 낮아지는 경향을 보였다. 이는 조류발생으로 인해 조류의 광합성을 통한 일시적 $\mathrm{DO}$ 농도 상승이 일어날 수 있으나 장기적으로 보면 광합성으 로 생성되는 산소보다 호흡으로 사용하는 산소가 더 많고, 수표면을 덮은 조류로 인하여 DO 농도가 낮아짐에도 공기 중의 산소가 물속으로 용해되지 못하는 등 복합적인 이유가 존재하기 때문일 것이다. ${ }^{12)}$ 또한 남조류 발생 가능성이 높은 여름철에 수온 증가로 용존산소의 포화도가 낮은 것도 이유가 될 수 있다.

그 외 항목인 $\mathrm{pH}$ 및 클로로필-a와 남조류 세포수는 낙동강

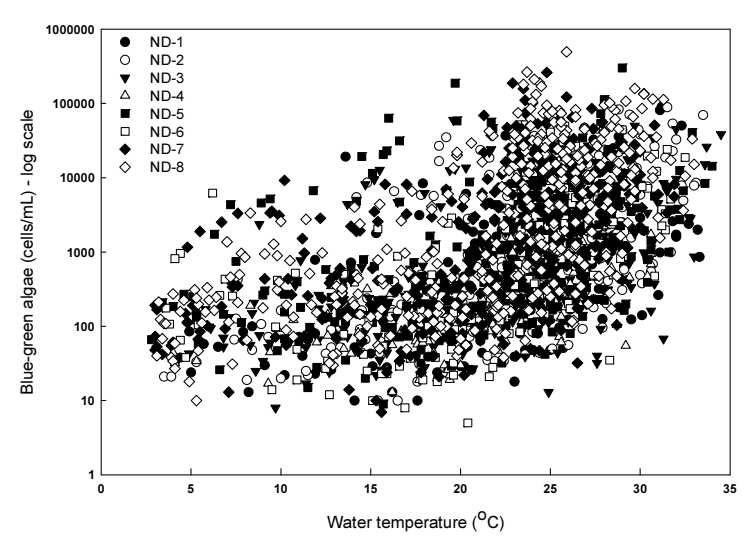

(A)

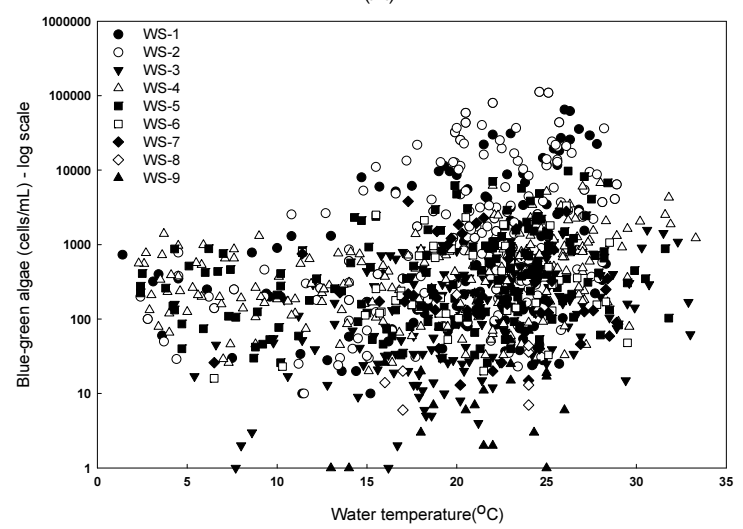

(B)

Fig. 5. The relation between blue-green algae occurred at study sites (A: ND-1 ND-8, B : WS-1 WS-9) vs. water temperature.

지점과 상수원 지점 모두 뚜렷한 상관관계가 없는 것으로 확 인되었다. 클로로필-a는 남조류 뿐만 아니라 규조류, 녹조류의 개체에도 포함이 되어 있고, 오히려 남조류의 클로로필-a 함유 량은 규조류나 녹조류에 비해 낮기 때문으로 판단된다. ${ }^{13,14)}$ 이에 환경부도 녹조현상과 상관관계가 낮은 클로로필-a 농도 를 2016년부터 조류경보제 수질항목에서 삭제하고 남조류 세 포수로 단일화하여 관리하고 있다. $\mathrm{pH}$ 는 유해남조류 개체 성 


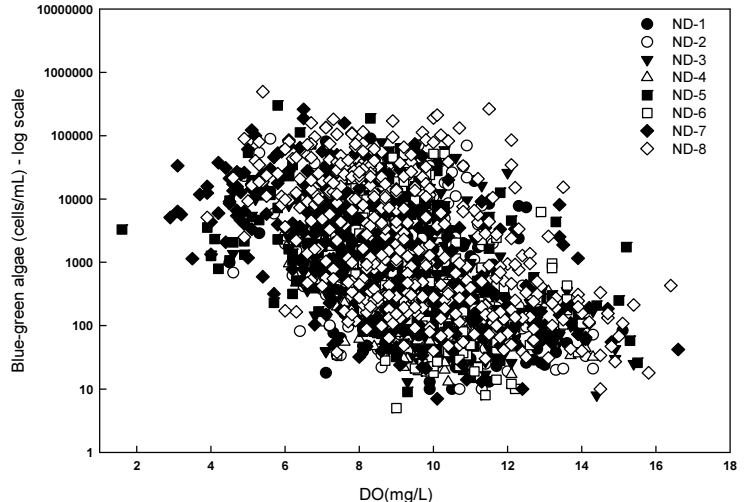

(A)

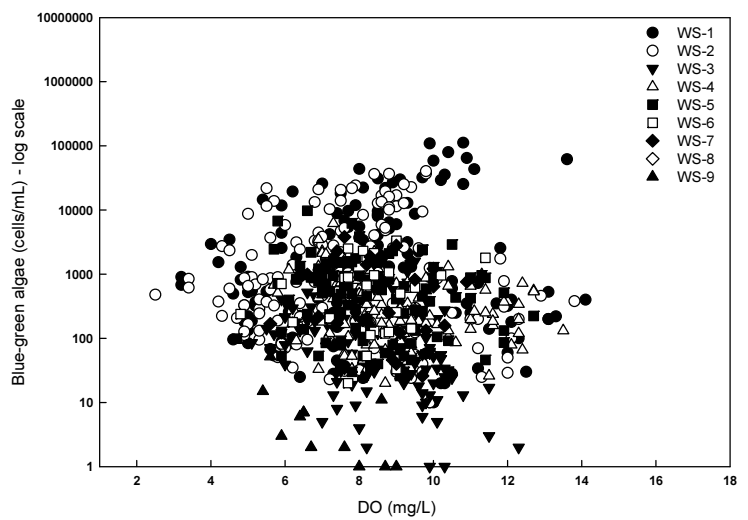

(B)

Fig. 6. The relation between blue-green algae occurred at study sites (A: ND-1 ND-8, B : WS-1 WS-9) vs. dissolved oxygen (DO) concentration.

장에 영향을 주는 인자이나 $\mathrm{pH}$ 7.7 9.4 범위인 약알칼리성 환경에서만 생장이 잘 일어나고 이 범위를 벗어나면 사멸하거 나 활성이 떨어지는 특성을 보이기 때문에 양 혹은 음의 상관 계수로는 높은 상관성을 보이지 못하는 것으로 판단된다. ${ }^{15}$

한편 본 연구에서는 자료가 미흡하여 분석하지 못했으나 물속의 영양염류, 특히 인(P)의 농도도 조류 세포수와 밀접한 관계가 있다. 미국 환경보호청(USEPA)에 따르면 조류 번성을 억제하기 위한 인의 한계농도는 $0.02 \mathrm{mg} / \mathrm{L}$ 로 알려져 있고 ${ }^{16}$ 인 농도에 따라 조류 발생이 제어된다는 연구결과도 다수 존재한다. ${ }^{17)}$ 남조류의 발생은 그 외에도 다양한 수질인자와 유역의 특성에 따라 영향을 받을 수 있고 복잡한 양상을 보임 으로 ${ }^{18-24)}$ 단순히 몇 가지 인자로만 설명하기에는 부족하다. 다만, 본 연구의 결과로만 보면 대구·경북지역 낙동강 유역의 남조류 발생은 수온의 영향을 크게 받는 것으로 판단된다.

\section{4. 결 론}

조류경보제와 수질예보제로 관리 되고 있는 대구·경북지역 낙동강 수계 및 상수원 지점의 2012년부터 2019년 사이 유해 남조류 발생 현황에 대하여 분석한 결과, 아래와 같은 결론을 얻었다.
1) 대구·경북지역 내 조류경보제 및 수질예보제로 관리되고 있는 수계에서 남조류 세포수는 상수원 지점(9개소)보다 낙동 강 지점(8개소)에서 더 높게 나타났다.

2) 낙동강 지점의 유해남조류 발생은 하류로 갈수록 정도가 심해지고 보와 보 사이의 지점보다 보 인근에서 더 높은 발생 정도를 보였다.

3) 낙동강 지점에서는 Microcystis가 우점종으로 나타났고 하류로 갈수록 Microcystis의 비율이 다소 증가하는 추세를 나타냈다. 상수원 지점은 지점에 따라 우점비율이 다르게 나 타나 Microcystis 또는 Aphanizomenon이 우점종이었다.

4) 유해남조류의 발생은 수온 증가 및 DO 농도 감소와 밀접 한 연관이 있었으나, Chl-a는 유해남조류 발생을 예측하는 인 자로서 상관성이 낮았다.

\section{Acknowledgement}

이 연구는 2018년 정부(과학기술정보통신부)의 재원으로 국가 과학기술연구회 창의형 융합 연구사업(No. CAP-18-07-KICT) 의 지원을 받아 수행되었습니다.

\section{References}

1. S. J. Hwang, Forecasting system for water quality using artificial neural networks: the Kangjung-Koryung weir on the Nakdong River, Keimyung University(2012).

2. S. H. Lee, B. R. Kim, H. W. Lee, A study on water quality after construction of the weirs in the middle area in Nakdong river, J. Korean Soc. Environ. Eng., 36(4), 258-264(2014).

3. S. M. Lee, I. K. Kim, Analysis of correlation between cyanobacterial population and water quality factors in the middle and down stream region of nakdong river, J. Korean Soc. Water Wastewater, 31(1), 93-101(2017).

4. H. J. Son, Long-term variations of phytoplankton biomass and water quality in the downstream of Nakdong river, J. Korean Soc. Environ. Eng., 35(4), 263-267(2013).

5. Y. S. Sin, C. H. Lee, K. A. Cho, E. S. Song, Trends of phytoplankton community and water quality and impalications for management in estuarine river systems, Korean J. Limnol., 38(2), 160-180(2005).

6. M. J. Harke, M. M. Steffen, C. J. Gobler, T. G. Otten, S. W. Wilhelm, S. A. Wood, H. W. Paerl, A review of the global ecology, genomics, and biogeography of the toxic cyanobacterium, Microcystis spp., Harmful Algae, 54, 4-20(2016).

7. Ministry of Environment, Annual Report on the Occurrence and Response of Algae (Alage Bloom) in 2017(2018).

8. D. Y. Park, H. S. Park, S. J. Kim, S. W. Chung, Analysis of water quality variation by lowering of water level in Gangjeong-Goryong weir in Nakdong river, J. Environ. Impact Assess., 28(3), 245-262(2019).

9. J. J. Yu, H. J. Lee, K. L. Lee, H. S. Lyu, J. H. Whang, L. Y. Shin, S. U. Chen, Relationship between distribution of the 
dominant phytoplankton species and water temperature in the Nakdong river, Korea, Korean Journal of Ecology and Environment, 47(4), 247-257(2014).

10. H. S. Ryu, R. Y. Shin, J. H. Lee, Response of growth and toxigenicity to varying temperature and nutrient conditions in Aphanizomenon flos-aquae(cyanophhyceae), J. Korean Soc. Water Environ., 33(5), 538-545(2017).

11. Y. N. Shin, J. Y. Lee, S. A. Yoon, S. S. Pak, K. L. Lee, J. S. Moon, H. G. Jeong, S. Y. Noh, S. W. Lee, H. J. Kim, B. J. Lim, J. J. Lee, J. H. Yoon, J. W. Lee, A study on the characteristics of algae blooms in rivers and reservoirs of Korea (I) -focused on the Geum river watershed-, National Institute of Environmental Research(2018).

12. S. Y. Noh, Y. N. Shin, H. L. Choi, J. Y. Lee, J. A. Lee, D. H. Rhew, Characteristics of algae occurrence on environmental changes, J. Environ. Impact Assess., 24(3), 278-286(2015).

13. T. K. Kim, J. H. Choi, K. J. Lee, Y. B. Kim, S. J. Yu, Study on introduction to predicting indicator of cyanobacteria dominance in algae bloom warning system of Hangang basin, J. Korean Soc. Environ. Eng., 36(5), 378-385(2014).

14. M. Gleitz, S. Grossmann, R. Scharekm, V. Smetacek, Ecology of diatom and bacterial assemblages in water associated with melting summer sea ice in the Weddell Sea, Antarctica. Antarct. Sci., 8(2), 135-146(1996).

15. J. J. Yu, H. J. Lee, K. L. Lee, I. J. Lee, G. Y. Jung, S. U. Cheon, Effects of environmental factors on algal communities in the Nakdong river, J. Korean Soc. Water Environ., 33(5), 539-548(2014).

16. S. I. Choi, What should be done to vanish algal bloom?, Journal of the Korean Society of Civil Engineers, 66(7), 10-13(2018).

17. D. W. Shindler, R. E. Hecky, D. L. Findlay, M. P. Stainton, B. R. Parker, K. G. Beaty, M. Lyng, S. E. M. Kasian, Eutrophication of lakes cannot be controlled by reducing nitrogen input: results of a 37-year whole-ecosystem experiment, PANS, 105(32), 11254-11258(2008).

18. M. A. Saxton, R. J. Arnold, R. A. Bourbonniere, R. M. L. Mckay, S. W. Wilhelm, Plasticity of total and intracellular phosphorus quotas in Microcystis aeruginosa cultures and lake Erie algal assemblages, Front. Microbiol., 3(3), 1-9(2012).

19. H. W. Paerl, H. Xu, N. S. Hall, G. Zhu, B. Qin, Y. Wu, K. L. Rossignol, L. Dong, M. J. McCarthy, A. R. Joyner, Controlling cyanobacterial blooms in hypertrophic Lake Taihu, China: will nitrogen reductions cause replacement of Non- $\mathrm{N}_{2}$ fixing by $\mathrm{N}_{2}$ fixing taxa?, Plos one, 9(11), e113123(2014).

20. H. W. Paerl, Mitigating harmful cyanobacterial blooms in a human- and climatically-impacted world, Life, 4(4), 988-1012(2014).

21. K. E. Havens, T. Fukushima, P. Xie, T. Iwakuma, R. T. James, N. Takamura, T. Hanazato, T. Yamamoto, Nutrient dynamics and the eutrophication of shallow lakes Kasumigaura (Japan), Donghu (PR China), and Okeechobee (USA), Environ. Pollut., 111(2), 263-272(2001).

22. H. W. Paerl, H. Xu, N. S. Hall, K. L. Rossignol, A. R. Joyner, G. Zhu, B. Qin, Nutrient limitation dynamics examined on a multiannual scale in Lake Taihu, China: implications for controlling eutrophication and harmful algal blooms, J. Freshw. Ecol., 30(1), 5-24(2015).

23. J. Kromkamp, A. Heuvel, L. R. Mur, Phosphorus uptake and photosynthesis by phosphate-limited cultures of the cyanobacterium Microcystis aeruginosa, Brit. Phycol. J., 24(4), 347-355(1989).

24. W. K. Dodds, K. R. Johnson, J. C. Priscu, Simultaneous nitrogen and phosphorus deficiency in natural phytoplankton assemblages: theory, empirical evidence, and implications for lake management, Lake Reservoir Manag., 5(1), 21-26(1989).

\section{Authors}

\section{Chang Yeon Woo}

Department of Environmental Engineering, Kumoh National Institute of Technology, Graduate Student, ORCID (1) 0000-00022569-6740

\section{Sang Leen Yun}

Korea Institute of Civil Engineering and Building Technology, Senior Researcher

\section{Seog-ku Kim}

Korea Institute of Civil Engineering and Building Technology, Senior Research Fellow

\section{Wontae Lee}

Department of Environmental Engineering, Kumoh National Institute of Technology, Professor, ORCiD(1) 0000-0001-96604455 